\title{
O CONTRATOS DE TRANSFERÊNCIA DE TECNOLOGIA E OS LIMITES À AUTONOMIA PRIVADA*
}

\author{
TECHNOLOGY TRANSFER CONTRACTS \\ AND THE LIMITS TO PRIVATE AUTONOMY
}

\author{
Valkíria Aparecida Lopes Ferraro \\ Jussara Seixas Conselvan ${ }^{* * * *}$
}

\begin{abstract}
Resumo: Uma característica distintiva dos Contratos de Transferência de Tecnologia é a intervenção estatal, cuja conseqüência é a limitação da liberdade de contratar das partes. A partir de uma reflexão sobre a intervenção estatal, são apontados fundamentos para os limites impostos pelos Estados, em seu âmbito interno, e pela ordem internacional. Conceitua-se tecnologia e caracteriza-se a sua transferência, enunciando as modalidades e cláusulas dos contratos. Indica-se como é exercido o controle na formação dos contratos no Brasil, principalmente através do Instituto Nacional de Propriedade Industrial (INPI). Apresenta um histórico da intervenção e as normas cogentes que regulam o conteúdo do contrato.
\end{abstract}

Palavras-chave: Contratos. Transferência. Tecnologia. Autonomia privada.

\begin{abstract}
A distinctive characteristic of Technology Transfer Contracts is the State intervention, whose consequence is the limitation of freedom to establish their content. From a reflection on State intervention, reasons for the limits are pointed out, inside the countries and in the international context. Technology and its transfer are defined, establishing the modalities and clauses of contracts. This paper indicates how control works in Brazil, mainly through the National Institute of Industrial Property (INPI). It presents a historical description of intervention and of the laws that regulate the content of the contract.
\end{abstract}

Key-words: Contracts. Transfer. Technology. Private autonomy.

Este artigo foi extraído do projeto de dissertação de Mestrado em Direito Negocial da Universidade Estadual de Londrina, na área de concentração de Direito Civil.

*.. Doutora em Direito das Relações Sociais pela Pontifícia Universidade Católica de São Paulo. Mestre em Direito das Relações Sociais pela Universidade Estadual de Londrina. Professora titular da Universidade Estadual de Londrina. Graduação em Direito pela Universidade Estadual de Londrina. Email: mariana99@sercomtel.com.br

Mestranda em Direito Negocial da Universidade Estadual de Londrina. Especialista em Direito da Integração e do Comércio Internacional pela Universidade Estadual de Londrina em Convênio com a Universidad Rey Juan Carlos de Madrid. Especialista em Direito Empresarial pela Universidade Estadual de Londrina. Advogada. Email: conselva@sercomtel.com.br. 


\section{INTRODUÇÃO}

No atual processo de globalização, a tecnologia é de fundamental importância. As empresas, em especial, necessitam de inovação tecnológica para serem competitivas nos mercados interno e externo.

Com o aumento do fluxo de tecnologia, principalmente com a ampliação dos mercados em razão do comércio internacional e da integração econômica, os negócios jurídicos cresceram substancialmente.

Nesse sentido, os contratos são fundamentais, uma vez que a transferência de tecnologia é realizada, em grande parte, através de contratos privados.

Todavia, uma característica distintiva dos contratos de transferência de tecnologia é a intervenção estatal e, por conseguinte, a limitação da liberdade de contratar das partes (DANNEMANN, 2001).

Assim, é oportuno verificar quais são os limites impostos à autonomia das partes pelos Estados, em seu âmbito interno, e pela ordem internacional. Para isso, insta saber por que e como é exercido o controle na formação e execução dos contratos e quais são as normas cogentes que regulam o seu conteúdo, principalmente no Brasil.

Para entender as razões do controle, é necessária uma reflexão sobre a intervenção estatal, especialmente no que tange à contratação entre entes privados, tendo em vista a perspectiva do Direito Econômico.

Dentro desse panorama, os Contratos de Transferência de Tecnologia serão investigados com o objetivo de determinar suas principais modalidades e cláusulas, bem como compreender o que é tecnologia e sua transferência, partindo da hipótese de que são um importante instrumento jurídico, cada vez mais utilizado no comércio internacional.

É importante observar, ainda, a questão da autonomia privada nos contratos de transferência de tecnologia. Na seqüência, perpassando a normativa internacional, tratar-se-á de suas limitações pela normativa nacional, no caso a ordem jurídica brasileira, com destaque para o papel do Instituto Nacional de Propriedade Industrial (INPI).

\section{A INTERVENÇÃO ESTATAL NOS CONTRATOS}

Durante o século XX, a atuação do Estado no campo econômico cresceu notoriamente. A figura do Estado intervencionista se supera, pois a palavra intervenção dá a idéia de transitoriedade, uma ingerência seguida de retirada. No entanto, "o Estado não mais intervém no sistema econômico. Integra-o" (NUSDEO, 2001, p. 186). 
À intervenção estatal no mercado denomina-se sistema econômico dual ou misto, e há quatro modalidades pelas quais o Estado pode se fazer presente: direção, absorção, participação e indução (EROS GRAU, apud NUSDEO, 2001, p. 195).

Neste trabalho, verifica-se a primeira modalidade - direção - em que há a imposição de uma conduta obrigatória aos agentes econômicos privados, através de normas de caráter legal ou regulamentar. Um exemplo característico de ação estatal por direção é o dirigismo contratual, em que há determinações cogentes quanto a cláusulas que devem ou não constar de contratos privados de caráter civil ou comercial (NUSDEO, 2001).

Assim, a liberdade contratual é aceita dentro de determinados parâmetros, sofre restrições pela ampliação da idéia de ordem pública e pela aplicação, nas devidas proporções, do conceito de função social.

Quando essa ação estatal era fundamentada no poder de polícia, as restrições ou limitações à liberdade tinham um caráter negativo, ou seja, impedir malefícios provocados por certas atividades.

Ao se atribuir a idéia de uma função social ao contrato, a visão passou a ser positiva, ou seja, não somente deixar de criar efeitos nocivos, mas criar benefícios à sociedade, ainda que indiretos (NUSDEO, 2001).

No entanto, o sistema dual comporta controvérsias sobre o quanto de Estado e o quanto de mercado devem coexistir e em que setores o Estado deve atuar. Não há respostas conclusivas para essas questões, pois o quanto dependerá de decisões políticas baseadas nas doutrinas econômicas de cada sociedade. Ademais, a decisão de quais setores requerem a presença do Estado também é de cunho político.

Diante disso, as Constituições passaram a incluir direitos de caráter econômico e social e a contemplar, expressamente ou não, programas para o aperfeiçoamento do sistema econômico, além das garantias individuais e a organização do Estado.

Passaram a ser denominadas constituições programa (por fixarem objetivos ou metas) e levaram à superação da idéia das constituições garantia. Também são chamadas de constituições social-democratas. Os autores alemães falam em constituição econômica, que fornece as bases para a ação do Estado na vida econômica.

A finalidade desses dispositivos de caráter econômico é estabelecer a possibilidade jurídica de o Estado se fazer presente no processo econômico, dentro de limites e condições. São denominadas de normas programáticas, pois indicam objetivos a serem implementados e servem de parâmetros para outras normas. 
No Brasil, a Constituição Federal de 1988 (CF 88) traça algumas diretrizes, contando com dois capítulos nesse sentido: Da Ordem Econômica e Financeira (VII) e Da Ordem Social (VIII).

Os arts. 170 a 174 da CF 88 definem o sistema econômico brasileiro como dual ou misto, configurando-se as várias modalidades de ação do Estado: direção, absorção, participação, indução (NUSDEO, 2001).

Uma vez que a incidência da política econômica sobre questões relacionadas à tecnologia é fundamental para a realização dos objetivos traçados para o Estado, de acordo com os arts. 218 e 219 da CF 88, verifica-se um fundamento para a intervenção específica nos contratos de transferência de tecnologia.

Dessa forma, a intervenção do Estado busca, além do efetivo equilíbrio entre as partes, fazer do contrato de transferência de tecnologia um instrumento útil à condução da política econômica.

Com isso, entende-se que, a partir da intervenção estatal, são criados limites à autonomia das partes nos contratos de transferência de tecnologia. Para tratar melhor dessa questão com base na normativa internacional e nacional, tratarse-á de esclarecer, na seqüência, termos e definições relativos a esses contratos.

\section{A CONTRATAÇÃO DE TRANSFERÊNCIA DE TECNOLOGIA}

Importa conceituar tecnologia e sua transferência, bem como o contrato de transferência de tecnologia, visto que há diferenças nos diversos níveis em que são tratados, a saber, na legislação, doutrina e jurisprudência, no âmbito nacional e internacional. Além disso, são destacadas as cláusulas relevantes nesses contratos.

\subsection{A Tecnologia}

Tecnologia, objeto de contratação, pode ter distintas definições. Uma delas refere-se à aplicação do conhecimento científico no meio técnico, para obter novo produto, processo industrial ou serviço. É um dos fatores empresariais e se insere nos direitos de propriedade intelectual (PIMENTEL, 2005).

Assim, "tecnologia abrange a maior parte das formas de conhecimento industrial, não só os resultados da investigação científica, como também a sua aplicação industrial, produção e comercialização" (ANTUNES; MANSO, 1993, p. 43).

De forma ampla, há autores que entendem que a tecnologia se soma aos fatores de produção clássicos: natureza, capital, trabalho e organização da atividade econômica (CORRÊA, 2005).

Então, "a tecnologia pode ser definida como um conjunto de conhecimentos aplicáveis na atividade produtiva” (CORREAA, 2005, p. 31). 
A tecnologia pode ser classificada em tecnologia patenteada e não patenteada. A primeira refere-se ao conhecimento das técnicas formalmente protegidas pelo Direito (patentes). A segunda, aos conhecimentos não patenteáveis (PIMENTEL, 1994), ou mesmo aqueles conhecimentos que poderiam ser patenteados, mas que são mantidos em segredo ou deixam de ser protegidos, recaindo no domínio público.

\subsection{A Transferência de Tecnologia}

A transferência de tecnologia é um negócio jurídico pelo qual uma das partes obriga-se a transmitir conhecimentos aplicáveis a um processo produtivo, sendo remunerado pela outra (CORRÊA, 2005), ou, ainda, quando há troca de conhecimentos ou comunhão de patentes.

Há quem considere que a transferência ocorre quando há o repasse do conhecimento, não a mudança de título. Esta foi a posição de 120 multinacionais em uma pesquisa do Estado Americano (Council of Americas), em 1978 (BARBOSA, 2003).

Isto porque a transferência de tecnologia entre países desenvolvidos pode gerar novas tecnologias, constituindo um fator de produção de tecnologia nova. Já a transferência para países subdesenvolvidos aparece somente como um fator de produção de bens e serviços, uma vez que não se reproduz. Funciona mais como um insumo, do que propriamente transferência, posto que normalmente não há assimilação, aperfeiçoamento ou adaptação, a tal ponto que há autores que entendem que se trata verdadeiramente de "arrendamento de um fator de produção”, mais do que transferência (BARBOSA, 2003, p. 991).

Esse ponto de vista é reforçado nos casos em que, findo o contrato, não se pode mais utilizar a tecnologia, nem como um simples insumo da produção.

Assim, nem sempre a venda de tecnologia significa verdadeira transferência, que é caracterizada pela sua absorção, que permite adaptar, aperfeiçoar, criar novas tecnologias, de forma autônoma. A crítica que se faz é que o que ocorre, na verdade, é uma venda, onde o vendedor vende as instruções e esconde os conhecimentos (CORRÊA, 2005).

Cabe, ainda, mencionar que se discute se a tecnologia equivale a uma mercadoria, ou seja, passível de comércio. Embora possam estar dissociados, quando há a transferência tecnológica sem o comércio, adota-se, neste estudo, o conceito de Transferência de Tecnologia como "processo de comercialização de um bem que se constitui em fator cognitivo da atividade empresarial" (BARBOSA, 2003, p. 990). 


\subsection{Os Contratos de Transferência de Tecnologia}

Os contratos de licenciamento ou de transferência de tecnologia podem ser definidos como "acordos de transferência de conhecimentos técnicos associados a determinado Know-how, celebrados entre um agente detentor do "conhecimento" e um agente interessado na sua utilização, nomeadamente para fins industriais" (ANTUNES; MANSO, 1993, p. 41). Ou seja, o titular ou detentor licencia ou cede a outrem conhecimentos tecnológicos, experiência sobre procedimentos ou fórmulas de produção de bens e serviços ou direitos de propriedade intelectual.

Há contratos que têm por objeto o conhecimento protegido pelos direitos de propriedade intelectual, como marcas, patentes, direitos autorais, direitos sobre programa de computador, e outros tecnologias, não necessariamente protegidas, como segredos e Know How.

Barbosa divide os contratos em quatro grupos: (i) contratos de propriedade intelectual (licenças, autorizações, cessões, etc.); (ii) contratos de segredo industrial e similares (inclusive franchising); (iii) contratos de projeto de engenharia; (iv) contratos de serviços em geral (BARBOSA, 2003, p. 966). Flores (2003, p. 90 ) inclui os contratos de informática.

Já o INPI tem reconhecido oito tipos de contratos: cessão e exploração de patentes, cessão e uso de marcas, fornecimento de tecnologia, franquia, assistência técnica e científica, participação nos custos de pesquisa e desenvolvimento tecnológico.

O Banco Central relaciona as sete primeiras categorias acima reconhecidas pelo INPI e aceita as demais modalidades que vierem a ser averbadas pelo mesmo.

A legislação tributária brasileira referente ao Imposto de Renda da Pessoa Jurídica (IRPJ) classifica os contratos em exploração ou cessão de patentes, uso ou cessão de marcas, transferência de tecnologia (assistência técnica, científica, administrativa ou semelhantes), transferência de tecnologia (projetos ou serviços técnicos especializados).

Importa destacar que, no Brasil, a nomenclatura dos contratos varia na legislação tributária, no INPI e no Banco Central. A confusão maior reside na noção de assistência técnica da legislação do IRPJ, que se adequa ao contrato de Know How, que o INPI, por sua vez, denomina Contrato de Fornecimento de Tecnologia. E o que o INPI nomeia Assistência Técnica, o IRPJ chama de contrato de projetos ou serviços técnicos especializados (BARBOSA, 2003.

Conforme a classificação do INPI, destaca-se a definição de cada um dos contratos de transferência de tecnologia: 
Exploração de Patentes (EP): contratos cujo objeto é o licenciamento de patente concedida ou pedido de patente depositado junto ao INPI.

Uso de Marcas (UM): contratos que têm como escopo o licenciamento de uso de marca registrada ou pedidos de registros depositados junto ao INPI.

Fornecimento de Tecnologia (FT): contratos que têm como finalidade a aquisição de conhecimentos e técnicas não protegidos por direitos de propriedade industrial, para a produção de bens industriais e serviços.

Prestação de Serviços de Assistência Técnica e Científica (SAT): contratos que estabelecem condições de obtenção de técnicas, métodos de planejamento e programação, bem como pesquisas, estudos e projetos para a execução ou prestação de serviços especializados.

Franquia (FRA): contratos que visam à concessão temporária de direitos que envolvam uso de marcas, prestação de serviços de assistência técnica, conjuntamente ou não, com qualquer outra modalidade de transferência de tecnologia necessária à realização de seu objetivo.

Como a tecnologia é extremamente mutável, surgem diferentes formas de comercializar, bem como muitas situações atípicas. Portanto, as cláusulas enumeradas abaixo servem apenas como orientação no estudo dos contratos de transferência de tecnologia.

Para Pimentel (2005), o contrato tem que ter, basicamente, a qualificação das partes, preâmbulo, objeto, preço, condições, propriedade intelectual, deveres das partes, solução de controvérsias e firmas.

Prado (1997), por sua vez, não utiliza a classificação tradicional das disposições contratuais (cláusulas essenciais, naturais e acidentais), e propõe critério classificatório específico, a saber: cláusulas centrais, complementares e usuais.

As cláusulas centrais são as diretamente relacionadas com a transferência e exploração da tecnologia pelo receptor. As principais são: objeto, definição da tecnologia, garantias de resultado, melhoramentos, território, sublicenciamento, assistência técnica e exploração mínima.

As cláusulas características dos acordos de transferência de tecnologia, mas que não se relacionam especificamente com ela, são denominadas cláusulas complementares, a saber: exclusividade, remuneração, confidencialidade e licença mais favorecida.

A terceira categoria refere-se às cláusulas usuais aos contratos internacionais: hardship, força maior, validade, termo inicial, duração, renovação, arbitragem, foro, lei aplicável.

Além dessas, Flores cita, ainda, os Incoterms, que se referem às cláusulas de garantia e de seguro (FLORES, 2003). 
Quanto ao contrato internacional, este se caracteriza pela presença de um elemento de estraneidade que o liga a dois ou mais ordenamentos jurídicos. (ARAÚJO, 2000).

No caso específico dos contratos internacionais de transferência de tecnologia, a natureza internacional reside no fato da transferência de bens ou serviços ocorrer de um país para outro, abrangendo ordens jurídicas distintas (FLORES, 2003).

Após a conceituação dos contratos de transferência de tecnologia e algumas de suas características, importa estudar os limites em sua contratação, conforme a ordem normativa.

\section{A AUTONOMIA PRIVADA NOS CONTRATOS DE TRANSFERÊNCIA DE TECNOLOGIA E AS LIMITAÇÕES NORMATIVAS}

Para estudar a questão da autonomia privada e suas limitações na contratação de transferência de tecnologia, importa tratar deste principio norteador da liberdade de comércio, e como ele é tratado na ordem interna e internacional e, consequentemente, as suas limitações.

O princípio da autonomia da vontade tem aplicações diferentes para civilistas e especialistas de Direito Internacional Privado. Para estes, indica a possibilidade de escolha da lei aplicável ao contrato, que funciona como uma regra de conexão autônoma (ARAÚJO, 2000).

No contexto do direito internacional privado, o que mais se discute na doutrina é a teoria da autonomia da vontade enquanto faculdade das partes de escolha da lei aplicável a um contrato internacional, não se sujeitando às regras de conexão do foro onde a questão será julgada (FLORES, 2003).

Assim, as partes podem determinar onde e como eventual litígio será julgado, através de cláusulas de foro e arbitragem, e qual a lei aplicável. Na ordem internacional, "a autonomia da vontade significa a liberdade das partes de escolherem outro sistema jurídico para regular o contrato” (ARAÚJO, 2000, p. 39).

Quando se escolhe a lei aplicável ao contrato, as partes optam por se submeter a um ordenamento jurídico e não a outro. Há, portanto, um direito aplicável (FLORES, 2003).

É importante salientar que as convenções internacionais permitiram expressamente a escolha da lei pelas partes. Com isso, houve a modificação da legislação interna de grande parte dos países para permitir a autonomia da vontade (ARAÚJO, 2000).

No Brasil, há três correntes doutrinárias quanto à escolha da lei aplicável: 
a primeira, contrária à autonomia da vontade; a segunda, a favor somente para regras supletivas, não se podendo aplicar ao contrato como um todo; e a terceira, favorável à teoria de forma ampla (ARAÚJO, 2000).

Ressalte-se que a Lei 9.307/96 adotou o princípio da autonomia da vontade no âmbito da arbitragem, tanto para dirimir controvérsias oriundas de contratos internos quanto internacionais (ARAÚJO, 2000).

Importa destacar que o que se pretende ressaltar neste trabalho são os limites ao conceito de autonomia privada enquanto liberdade de fixar o conteúdo material do contrato de transferência de tecnologia entre empresas brasileiras e empresas sediadas ou domiciliadas no exterior.

Para os civilistas, a utilização do conceito de autonomia da vontade não é mais apropriada. O conceito mais adequado é o da autonomia privada, que é o poder de regular os próprios interesses mediante a criação de negócios jurídicos (BETTI, 2003).

O paradigma liberal concebia os contratos como forma de expressão do princípio da autonomia da vontade (SALOMÃO FILHO, 2001), no sentido de liberdade para criar o contrato, contratar ou não, escolher o outro contraente e estipular o conteúdo do contrato.

Betti, já com a concepção de autonomia privada, assinala que qualquer negócio serve uma função econômico-social e que essa função ou razão se qualifica como causa do negócio jurídico. Aduz que o direito não sanciona o arbítrio, o motivo transitório e irrelevante, mas apenas funções socialmente relevantes e úteis para a comunidade. Se a vontade individual fosse onipotente, não se conheceriam os múltiplos limites sociais e jurídicos da autonomia privada (BETTI, 2003).

Os contratos de transferência de tecnologia têm, também, essa perspectiva funcional e social. Reconhecendo-se a sua influência na esfera social, admitese a "normatização" dos contratos, através da inserção de cláusulas que o compatibilizem com um mundo em que pretendem e podem influir. Nos setores regulados, principalmente naqueles em que há dominação do mercado, o contrato não influencia somente a relação das partes, mas também consumidores e concorrentes, existentes e potenciais. A regulação deve compatibilizar a negociação privada contratual com seus efeitos públicos (SALOMÃO FILHO, 2001).

Portanto, o estudo dos limites jurídicos impostos à autonomia das partes é relevante para que o contrato de transferência de tecnologia não seja nulo ou anulável (PRADO, 1997). 


\subsection{As Limitações na Ordem Internacional}

Quando se trata de transferência de tecnologia, não é possível estabelecer a clássica divisão do direito em público e privado. O direito internacional público passa a ser muito importante na harmonização dos contratos.

Assim, os limites em relação ao conteúdo dos contratos, estabelecidos pela ordem internacional, surgem em tratados e convenções internacionais com força coercitiva sobre os Estados, que visam a harmonizar e reforçar as legislações dos países sobre propriedade industrial e regular a livre concorrência na esfera dos mecanismos de integração regional (PRADO, 1997).

Importa destacar aqui algumas iniciativas que não resultaram ainda em questões práticas, mas de grande relevância sobre o assunto. Uma delas é a da Comissão das Nações Unidas para Comércio Internacional (UNCITRAL), que fez vários estudos para criar normas internacionais para a regulamentação dos contratos, buscando harmonizar as normas indiretas, de direito internacional, face à dificuldade de harmonizar as legislações dos países (FLORES, 2003).

Além dela, a Conferência das Nações Unidas para o Comércio e Desenvolvimento (UNCTAD) fez exercícios com o intuito de estabelecer um Código Internacional de Conduta para a Transferência de Tecnologia. Não houve consenso, no entanto, entre os países desenvolvidos e os em desenvolvimento. Aqueles só queriam repudiar práticas lesivas à concorrência, estes as que interferissem no fluxo de tecnologia para o seu setor produtivo. Outra discórdia estava no tratamento dado a empresas do mesmo grupo econômico, em questões como controle de preços, direcionamento do mercado, etc. (BARBOSA, 2003).

Apesar disso, o Terceiro Mundo reivindica esse Código desde 1961, indicando vários problemas: os países ricos só transferem tecnologia aos pobres quando está ultrapassada; estes só têm 1\% do estoque mundial de patentes; transfere-se a técnica e não a tecnologia; não beneficia toda a sociedade, pois é feita para a filial ou subsidiária da empresa estrangeira; o preço é muito elevado; o processo de transferência aumenta a dependência dos países pobres (CELSO MELLO, apud FLORES, 2003).

Voltado para as iniciativas relativas ao direito internacional privado, não tratando especificamente de propriedade intelectual, o Instituto para Unificação do Direito Privado (UNIDROIT) foi criado em 1926, para harmonizar a legislação dos Estados. Elabora princípios que são fonte de direito nos Tribunais Internacionais.

No que tange às questões de direito internacional privado, a Convenção de Viena, de 1980, embora trate de compra e venda de mercadorias, é importante porque adotou o princípio da autonomia da vontade. Este documento é aplicado apenas pelos países signatários e que o ratificaram. 
Já com força coercitiva sobre os países signatários, o TRIPS (Trade Related Aspects of Intellectual Property Rights) é um instrumento concluído em 1994, no âmbito da Organização Mundial do Comércio, que regula e visa a harmonizar as legislações internas sobre propriedade intelectual, fundamental, portanto, para a transferência de tecnologia internacional.

O TRIPs ainda remete à Convenção de Paris, de 1883, alterada em 1967 pela Ata de Estocolmo, que estabelece princípios e garantias sobre propriedade industrial. Como conseqüência, surgiu a Organização Mundial sobre Propriedade Industrial (OMPI), para aprimorar essa legislação.

Nesse sentido, a legislação sobre propriedade industrial e sua comercialização, baseada em regra em tratados internacionais, tem sido o principal instrumento de proteção legal à tecnologia, desempenhando importante papel na facilitação das transferências internacionais (PRADO, 1997).

$\mathrm{Na}$ prática, diante da desigualdade entre as partes de um contrato internacional de transferência de tecnologia, verifica-se a existência de cláusulas restritivas e práticas abusivas à concorrência e que favorecem a dependência tecnológica dos países em desenvolvimento.

São exemplos de práticas restritivas: exclusividade de transações, retrocessão, fixação de preços, restrição e exportação (cláusulas de restrições territoriais), restrição e publicidade, restrição às adaptações, restrições após a expiração do acordo, cláusulas de não contestação.

Os abusos surgem em restrições sobre o montante a ser pago, prazo do contrato, limitações territoriais, preço, práticas concertadas (venda casada), abuso de posição dominante (CORRÊA, 2005).

Há que se considerar neste tópico a perspectiva que o TRIPs trouxe ao assunto, como em seu artigo 40.1, que dispõe: "Os Membros concordam que algumas práticas ou condições de licenciamento relativas a direitos de propriedade intelectual que restringem a concorrência podem afetar adversamente o comércio e impedir a transferência e disseminação de tecnologia”.

Predominou nesse artigo a posição dos países desenvolvidos de que são reprováveis as cláusulas que lesam regras concorrenciais.

Todavia, o art. 8 do TRIPs possibilita aos Membros formular ou emendar suas leis, para promover o interesse público, visando ao desenvolvimento sócioeconômico, e tomar "medidas apropriadas para evitar o abuso dos direitos de propriedade intelectual por seus titulares ou para evitar o recurso a práticas que limitem de maneira injustificável o comércio ou que afetem adversamente a transferência internacional de tecnologia".

Em ambos os casos, não serão permitidas cláusulas e práticas que abusem 
do direito de propriedade intelectual. "O abuso é essencial para a proibição" (BARBOSA, 2003, p. 1102). No caso do art. 40.2, o abuso é verificado sob a ótica da tutela da concorrência no mercado relevante.

Diante disso, a legislação nacional dos países membros pode reprimir essas práticas e condições de licenciamento (art. 40.2). Há uma permissão e não uma obrigação de rejeitar as referidas cláusulas, tendo em vista que somente as disposições de direito público externo referentes a consultas entre Estados têm aplicação imediata e direta (BARBOSA, 2003, p. 1099).

$\mathrm{O}$ art. 40.2 do TRIPs traz três exemplos de práticas abusivas (BARBOSA, 2003, p. 1105), mas que dependerão da "regra da razão", ou seja, não são proibições absolutas, mas que precisarão ser analisadas nas situações concretas dentro do contexto vigente:

a) cláusulas de retrocessão exclusiva, ou seja, que obrigam ao licenciado transferir exclusivamente ao titular da patente as melhoras feitas na tecnologia licenciada;

b) cláusulas que impeçam o licenciado impugnar a validade do direito licenciado;

c) obrigação de o licenciado adquirir do licenciante outras tecnologias ou materiais que não necessita ou deseja.

Além dessas três hipóteses, não há uma lista formal de cláusulas ilícitas. O TRIPs instaurou o parâmetro da legalidade para identificá-las. Por exemplo, conhecendo-se o conteúdo e os limites da patente, o que for excesso de poderes ou desvio de finalidade, será abusivo (BARBOSA, 2003, p. 1117). Primeiramente, verifica-se o abuso diante do direito da propriedade intelectual e, depois, se esse abuso prejudica a concorrência.

$\mathrm{Na}$ seqüência do que foi tratado, passa-se ao estudo das questões voltadas à ordem interna dos Estados, em específico do ordenamento jurídico brasileiro.

\subsection{As Limitações $\mathrm{Na}$ Ordem Interna}

Os limites de ordem interna são motivados por razões políticas, econômicas e de proteção ao particular nacional.

O Estado do transferente justifica, politicamente, o controle sobre o fluxo de tecnologia com o argumento de que "a riqueza nacional deve observar, necessariamente, os objetivos do Estado, em suas relações internacionais" (PRADO, 1997, p. 61). Além disso, preocupa-se com a não disseminação de conhecimento estratégico militar. O Estado do receptor também controla o ingresso de tecnologia por causa da defesa nacional e para evitar a dependência tecnológica.

No âmbito econômico, o Estado procura organizar as atividades de produção 
e distribuição de bens e serviços. Regulamenta os contratos de transferência de tecnologia, pois são fatores de desenvolvimento.

Já o Estado receptor preocupa-se com as remessas de recursos para o exterior, o equilíbrio da balança de pagamentos, controle do fluxo monetário, investimento estrangeiro e dependência econômica.

A defesa do particular nacional, considerado hipossuficiente diante de empresas transnacionais, é a terceira justificativa para a intervenção do Estado. Mas também não há como ignorar o fato de que Estados intervêm para defender os interesses das transnacionais e das economias mais desenvolvidas.

$\mathrm{Na}$ ordem internacional, o interesse estatal nas relações comerciais privadas é óbvio diante das quantias envolvidas nesses contratos. Isso se reflete nos tratados e aparecimento de organizações internacionais que buscam relações comerciais mais estáveis (FLORES, 2003, p. 45).

A dependência tecnológica é um dos efeitos da tecnologia que deve ser considerado e surge como resultado da desigualdade entre os países em desenvolvimento (adquirentes) e os desenvolvidos (produtores).

Outro aspecto que desperta o interesse estatal é a transferência de tecnologia de dupla finalidade, civil e militar. Por isso, há o controle para que alguns países não obtenham conhecimento para produzir armas ou equipamentos com finalidade militar. Esses países usam de expedientes para driblar o monitoramento, como adquirir tecnologia fracionada de diversos lugares.

Outras razões são indicadas, ainda, para a regulamentação dos contratos de transferência de tecnologia como o humanismo, a adequação à realidade, a proteção ao meio ambiente, a liberdade de concorrência e a eficiência de mercado (CORRÊA, 2005, p. 109-155).

Para o humanismo, o bem-estar material adquirido através da ciência e tecnologia deve ser conciliado com o desenvolvimento espiritual do homem voltado para sua humanidade. Não existe progresso autêntico nem desenvolvimento sustentado se não apoiado em sólidas bases morais, éticas e calcado em valores espirituais. Propõe-se o desenvolvimento da tecnologia com humanismo (DOLCE, apud CORRÊA, 2005, p. 115, 117).

A adequação à realidade é relevante uma vez que as tecnologias dos países industrializados nem sempre correspondem às necessidades e condições sócioeconômicas e ambientais dos adquirentes. Essa avaliação é importante para que não haja destruição de tecnologias locais, desemprego tecnológico, devastação ambiental e pagamentos por tecnologias desnecessárias.

Quanto à proteção do meio ambiente, há que se verificar que os recursos da natureza são esgotáveis e quais os impactos da degradação ambiental, 
especialmente para as futuras gerações. Assim, devem ser favorecidas as transferências de tecnologias que contribuam para o desenvolvimento não danoso, evitando transações com tecnologias poluentes que já se tornaram obsoletas nos países industrializados, além de buscar a adequação aos ecossistemas nacionais.

No que tange à liberdade de concorrência, há dois aspectos que devem ser considerados: primeiro, o desequilíbrio entre as partes nas transações tecnológicas, em relação aos poderes de negociação, principalmente quando envolve um país desenvolvido e outro em desenvolvimento; segundo, o contrato pode fortalecer os contratantes em detrimento dos demais agentes econômicos, prejudicando o equilíbrio do mercado. Dessa forma, o contrato pode conter abuso do poder econômico, que deve ser reprimido.

Já a eficiência é um critério do Direito Econômico para realizar o objetivo do desenvolvimento não danoso e para ponderar as condutas dos agentes econômicos na formulação e execução de políticas econômicas voltadas à regulamentação da tecnologia. Constitui, portanto, um critério para o controle das cláusulas abusivas e práticas restritivas.

\subsection{O Ordenamento Jurídico Brasileiro}

Internamente, o Estado interfere especialmente através de normas cogentes reguladoras do conteúdo do contrato e de ordem pública, controlando a sua formação e execução, bem como a remessa de remuneração para o exterior (PRADO, 1997, p. 64).

O princípio da autonomia privada é, portanto, limitado pela intervenção estatal no negócio jurídico (dirigismo contratual), ou seja, o Estado intervém no contrato, através de medidas restritivas, sobrepondo os interesses coletivos aos interesses individuais das partes, de acordo com a sua política econômica (DINIZ, 2006, p. 28).

Em contraposição, a sociedade busca negócios ágeis, sem a burocracia estatal e satisfazendo as vontades das partes.

O negócio jurídico resulta, portanto, do equilíbrio entre duas forças: a vontade das partes defendendo seus interesses econômicos e o Estado defendendo os interesses da coletividade (FLORES, 2003, p. 66).

\subsubsection{Histórico}

O Brasil é, predominantemente, um país importador de tecnologia, e isso tem sido usado como justificativa para a grande interferência do Estado e a regulamentação sobre o conteúdo dos contratos. Contudo, mesmo os países 
industrializados e exportadores de tecnologia, como os Estados Unidos da América e a Comunidade Européia, têm regulado os termos contratuais.

Historicamente, no Brasil, distinguem-se quatro fases na regulamentação das transferências de tecnologia: 1) até 1958, a responsabilidade era só dos contratantes; 2) de 1958 a 1970, o Estado intervinha para controlar as remessas para o exterior; 3) de 1970, principalmente de 75, até 1988, cresce o controle da negociação; 4) a partir de 1988, com a Constituição Federal e as Leis 8.884/94 (Lei da Concorrência) e 9.279/96 (Lei da Propriedade Industrial - LPI), houve mudança no perfil da regulamentação (BERKEMEIER, apud CORRÊA, 2005, p. 158).

$\mathrm{Na}$ terceira fase, em que a intervenção foi mais contundente, justificavase que era necessária para a assimilação de tecnologia indispensável para o desenvolvimento econômico do país, contrapondo-se à dependência tecnológica.

A Lei n. ${ }^{\circ}$ 5.648, de 11/12/70, instituiu o Instituto Nacional de Propriedade Industrial (INPI) como o órgão regulador e lhe outorgou poderes para tanto. A ingerência chegou ao ápice em 1975, com o Ato Normativo n.. 15 , em que eram enumeradas cláusulas obrigatórias e proibidas nos contratos de transferência de tecnologia.

\subsubsection{INPI}

O INPI é uma Autarquia Federal, vinculada ao Ministério do Desenvolvimento, Indústria e Comércio Exterior, cuja missão é executar, no âmbito nacional, as normas que regulam a propriedade industrial, tendo em vista a sua função social, econômica, jurídica e técnica.

Cabe-lhe também o pronunciamento sobre a conveniência de assinatura, ratificação e denúncia de convenções, tratados, convênios e acordos sobre propriedade industrial.

Atualmente, para que uma contratação tecnológica gere determinados efeitos econômicos, o contrato deve ser avaliado e averbado pelo INPI.

Por disposição da LPI, devem ser averbados/registrados pelo INPI todos os contratos que impliquem transferência de tecnologia, sejam entre empresas nacionais, ou entre empresas nacionais e sediadas ou domiciliadas no exterior (www.inpi.org.br).

$\mathrm{Na}$ seqüência, é necessário o registro no Banco Central (BACEN), para possibilitar a remessa de pagamento ao exterior.

No caso das patentes e marcas, os procedimentos são de averbação ou anotação no INPI, uma vez que são feitos à margem do ato de concessão do direito. Nos demais casos, existirá o registro, de acordo com o art. 211, da LPI.

Conforme o disposto nos artigos 60, 62, 137, 140 e 211, da Lei 9.279/96, 
o contrato tem eficácia entre as partes sem a averbação das licenças e cessões. Todavia, são indispensáveis para que haja eficácia relativa ou oponibilidade a terceiros.

Para o INPI, a averbação do contrato legitima pagamentos para o exterior; permite, quando for o caso, a dedutibilidade fiscal para a empresa cessionária dos pagamentos contratuais efetuados; e produz efeitos perante terceiros. Ademais, gera bancos de dados; estabelece níveis de pesquisa aplicada; gerencia desenvolvimento tecnológico; e possibilita formulação de política de transferência de tecnologia (www.inpi.org.br).

Há autores que entendem que, de acordo com a Lei 9.279/96, o INPI não teria mais o poder de intervenção nos contratos quanto à sua conveniência e oportunidade, já que a referida lei eliminou - dentre suas atribuições - a de regular a transferência de tecnologia e afirmar a política industrial vigorante, como o fazia a Lei 5.648/70, em seu artigo $2^{\circ}$, parágrafo único (LEONARDOS, apud BARBOSA, 2003, p. 983). Considera-se que o seu papel passou a ser mais restrito: de agente de intervenção a órgão registral (BARBOSA, 2003, p. 1131).

Todavia, as competências do INPI de assessor da Receita Federal e do Banco Central, na análise de questões a eles relacionadas, foram mantidas nas legislações tributária e cambial.

Aliás, há críticas no sentido de que, no contexto de regime de economia aberta, as normas do INPI parecem se preocupar mais com o preço da tecnologia e para as consequências tributárias, decorrente do interesse arrecadatório característico da atuação fiscal do Estado brasileiro (CORRÊA, 2005, p. 159).

Compete ao INPI, ainda, a análise de legalidade intrínseca e provocar a necessidade de pronunciamento do Conselho Administrativo de Defesa Econômica (CADE) quando o contrato possa violar as normas de concorrência em vigor. Entende-se que o INPI não tem competência para a repressão da concorrência desleal, tendo em vista que para a sua apuração é necessário um processo judicial com o devido processo legal. Tampouco seria competente para rejeitar cláusulas abusivas ao Direito do Consumidor (BARBOSA, 2003, p. 983 e 1128).

Então, se um contrato for encaminhado ao INPI para registro, e este entender que há abuso em alguma cláusula, deveria propor à parte alterá-la ou submetê-la ao CADE.

\subsubsection{Limitações}

O Ato Normativo 137/97, do INPI, que teve como escopo normalizar os procedimentos de averbação ou registro de contratos de transferência de 
tecnologia e de franquia, fundamenta a sua intervenção na LPI e na seguinte legislação complementar:

- Lei do Capital Estrangeiro (Lei no‥ 4131, de 3 de setembro de 1962);

- Normas regulamentares sobre o imposto de renda (Lei no ${ }^{\circ}$ 4506, de 30 de novembro de 1964 e Lei no. 8383, de 31 de dezembro de 1991);

- Lei de Programa de Computador (Lei nº. 7646, de 18 de dezembro de 1987, substituída pela Lei no . 9.609/98);

- Lei Antitruste (Lei no. 8884, de 11 de junho de 1994);

- Lei do Franchising (Lei no. 8955, de 15 de dezembro de 1994);

- Normas do TRIPS e Decreto Legislativo nº. 30, de 30 de dezembro de 1994, combinado com o Decreto Presidencial nº. 1355, da mesma data.

Constata-se que, a despeito da previsão da LPI de que a função do registro e averbação do contrato no INPI é a oponibilidade a terceiros, o órgão faz uma análise substantiva do contrato e pode fazer exigências e indeferir a pretensão de registro ou averbação.

Esse entendimento é corroborado pelo art. 2ํㅡㄹ da Resolução do INPI nํ. 94/2003, uma vez que caso haja exigência, essa deverá ser atendida pelo usuário em sessenta (60) dias a contar da data da ciência, sob pena do cancelamento do pedido.

Ademais, há um "entendimento do INPI", que são regras não escritas e resultantes do pensamento dos examinadores sobre determinada matéria (DANNEMANN, 2001, p. 445).

Embora os Atos Normativos n‥ 15/75 enㅇ․ 120/93 tenham sido expressamente revogados, continuam sendo a base para as decisões dos examinadores.

O Ato Normativo nº 15/75 listava as cláusulas restritivas. Embora não mais em vigência, as disposições que não eram mera intervenção na economia pela regulamentação discricionária de importação de tecnologia, podem ainda ser vedadas. Destaque-se, mais uma vez, que o “entendimento do INPI” também se baseia nesse regulamento.

Diante do disposto no art. 40.2 do TRIPs, a legislação nacional dos países membros pode reprimir práticas e condições de licenciamento. Ressalte-se, novamente, que há uma permissão e não uma obrigação de rejeitar as referidas cláusulas.

Dessa forma, o acordo não concede nenhum poder legal ao INPI, CADE ou Secretaria de Desenvolvimento Econômico (SDE) para avaliar e vetar contratos (BARBOSA, 2003, p. 1099).

Mas, até com embasamento nesse acordo, há a análise, no INPI, se há abuso diante do direito de propriedade intelectual e, depois, se esse abuso prejudica a concorrência.

Os doutrinadores citam alguns exemplos de limitações contratuais 
(BARBOSA, 2003, p. 985; DANNEMANN, 2001, p. 445):

a) Proibição de sigilo em contrato de prestação de serviços técnicos;

b) Proibição de sigilo superior a cinco (5) anos além do prazo contratual em contratos de fornecimento de tecnologia;

c) Proibição de que nos contratos de fornecimento de tecnologia haja a licença temporária de uso de uma tecnologia;

d) Proibição à cláusula de devolução de informações tecnológicas após o término contratual, nos contratos de fornecimento de tecnologia;

e) Estipulação de valores máximos para pagamento e remessa de royalties pelo uso dos direitos da propriedade industrial, nos contratos de empresas independentes, tendo como parâmetro a Portaria 436, de 30/12/58, do Ministério da Fazenda;

f) No caso de empresa com vínculo majoritário de capital, além dos níveis de mercado devem ser respeitados os limites estabelecidos na Lei $\mathrm{n}^{\circ}$. 4131/62 e na Portaria MF nº. 436/58, conforme artigo 50 da Lei $n^{\circ}$. 8.383/91.

g) Exigência de modificação da definição de "preço líquido de venda" para dedução dos preços dos insumos importados para fabricação dos produtos licenciados na definição da base de cálculo do pagamento dos royalties e remunerações dos contratos;

h) Proibição de remessa de royalties sobre as vendas efetuadas entre a assinatura do contrato e o protocolo para averbação no INPI.

Cabe repetir que pronunciamentos da Diretoria de Tecnologia do INPI sobre direito antitruste e do consumidor causam insegurança nas partes, tendo em vista o entendimento de que não tem legitimidade para isso.

\subsubsection{Exigências}

O INPI faz algumas exigências expressas (www.inpi.org.br), enquanto outras integram o "entendimento" dos examinadores mencionado anteriormente.

Os contratos de Exploração de Patentes deverão indicar o número e o título da patente e/ou pedido de patente, devendo respeitar o disposto nos Artigos 61, 62, 63 e 121 da Lei no. 9279/96 - Lei da Propriedade Industrial.

Os contratos de Uso de Marcas deverão indicar o número e a marca registrada ou depositada, devendo respeitar o disposto nos Artigos 139 e 140 da Lei no 9279/96 - Lei da Propriedade Industrial.

Nos contratos de Prestação de Serviços de Assistência Técnica e Científica será exigida a explicitação do custo de homem/hora detalhado por tipo de técnico, o prazo previsto para a realização do serviço ou a evidenciação de que o mesmo já fora realizado e o valor total da prestação do serviço, ainda que estimado. 
O Contrato de know How deve determinar se a licença é exclusiva ou não, bem como a possibilidade de sublicenciamento.

Nos contratos em geral, as formas e os prazos de pagamento são negociáveis, mas devem ser levados em conta os níveis de preços praticados nacional e internacionalmente em contratações similares.

Os contratos de transferência de tecnologia em geral são averbados por um prazo máximo de 5 (cinco) anos conforme a Lei no. 4131/62, excetuando-se os que tenham por objeto direitos de propriedade industrial. As licenças de patentes ou marcas são averbáveis pelo prazo de validade desses privilégios.

\section{CONCLUSÃO}

Com a globalização, a tecnologia tornou-se essencial para a competitividade das empresas e, muitas vezes, é necessário importá-la de outros países. Com o aumento do comércio internacional, os negócios jurídicos cresceram substancialmente.

Nesse contexto, os contratos são fundamentais, já que a transferência de tecnologia é realizada, geralmente, através de contratos privados.

Ao buscar estabelecer as principais cláusulas do contrato de transferência de tecnologia, constatou-se a existência de limites à Autonomia Privada, no sentido de restrições à liberdade de fixar o conteúdo do contrato. Observou-se que esse princípio tem aplicações diferentes para civilistas e especialistas de direito internacional. Para aqueles, refere-se à possibilidade das partes disciplinarem seus interesses como melhor lhes parecer, enquanto, para estes, indica a possibilidade de escolher a lei aplicável ao contrato.

Foi identificada, assim, uma característica que distingue esses contratos, qual seja, a intervenção estatal, sobrepondo os interesses coletivos aos interesses individuais das partes, de acordo com a sua política econômica. Nesse sentido, coube uma reflexão sobre a intervenção do Estado, delineado na Constituição Federal e sob a ótica do Direito Econômico.

Verificou-se que uma das modalidades pelas quais o Estado pode se fazer presente no sistema econômico dual é a direção, cujo exemplo característico é o dirigismo contratual: determinações cogentes quanto a cláusulas que devem ou não constar dos contratos privados. Há restrições pela ampliação da idéia de ordem pública e pela aplicação, nas devidas proporções, do conceito de função social.

Observou-se, entretanto, controvérsias sobre o quanto o Estado deve intervir e em que setores deve atuar. Isso dependerá de decisões políticas baseadas nas doutrinas econômicas de cada sociedade. 
No caso brasileiro, a Constituição Federal de 1988 contempla a possibilidade jurídica de o Estado se fazer presente no processo econômico em dois capítulos: Da Ordem Econômica e Financeira (VII) e Da Ordem Social (VIII).

Os arts. 170 a 174 da CF 88 definem o sistema econômico brasileiro como dual ou misto, configurando-se as várias modalidades de ação do Estado: direção, absorção, participação, indução. E, de acordo com os arts. 218 e 219 da CF 88, a tecnologia é fundamental para a realização dos objetivos traçados para o Estado. Por conseguinte, este busca fazer do contrato de transferência de tecnologia um instrumento útil à condução da política econômica.

Complementando esse raciocínio, foram abordadas razões para os limites impostos pelos Estados, em seu âmbito interno, e pela ordem internacional, a saber: políticas (conhecimento estratégico militar, defesa nacional e dependência tecnológica); econômicas (tecnologia como fator de desenvolvimento, remessas de recursos para o exterior, equilíbrio da balança de pagamentos, controle do fluxo monetário, investimento estrangeiro e dependência econômica) e de proteção ao particular nacional (considerado hipossuficiente diante de empresas transnacionais). Outros fundamentos são indicados, ainda, para a regulamentação dos contratos de transferência de tecnologia: humanismo, adequação à realidade, proteção do meio ambiente, liberdade de concorrência, eficiência.

Foram enumerados os principais tratados, convenções e instâncias onde surgem os limites estabelecidos internacionalmente e que visam a harmonizar e reforçar as legislações dos países sobre propriedade intelectual e regular a livre concorrência, dentre eles: UNCITRAL, OMPI, UNIDROIT, TRIPS, UNCTAD, Convenção de Viena e Convenção de Paris.

Delimitaram-se três hipóteses previstas no TRIPs como cláusulas abusivas, uma vez que o mesmo instaurou o parâmetro da legalidade para determiná-las: primeiramente, verifica-se o abuso diante do direito de propriedade industrial e, depois, se esse abuso prejudica a concorrência.

Dentre as definições de tecnologia, optou-se pela que a descreve como um conjunto de conhecimentos aplicáveis na atividade produtiva. A transferência de tecnologia, por sua vez, ocorre quando há assimilação que permite adaptar, aperfeiçoar, criar novas tecnologias, de forma autônoma.

A internacionalidade do contrato caracteriza-se pela presença de um elemento de estraneidade que o liga a dois ou mais ordenamentos jurídicos.

Considerou-se bastante pertinente a sistematização das cláusulas contratuais em cláusulas centrais (diretamente relacionadas com a transferência da tecnologia: objeto, definição da tecnologia, garantias de resultado, 
melhoramentos, território, sublicenciamento, assistência técnica e exploração mínima); complementares (características dos acordos de transferência de tecnologia, mas que não se relacionam especificamente com ela: exclusividade, remuneração, confidencialidade e licença mais favorecida) e usuais (comuns nos contratos internacionais: hardship, força maior, validade, termo inicial, duração, renovação, arbitragem, foro, lei aplicável).

Foram enfocadas as modalidades de contratos previstas no INPI: cessão e exploração de patentes, cessão e uso de marcas, fornecimento de tecnologia, franquia, assistência técnica e científica, participação nos custos de pesquisa e desenvolvimento tecnológico.

Constatou-se a possibilidade de existência de práticas abusivas e cláusulas restritivas nos contratos de transferência de tecnologia. Verificou-se que o controle no Brasil ocorre principalmente através do registro ou averbação do contrato no INPI, previsto na Lei da Propriedade Industrial (LPI) - Lei no 9.279/96.

Atualmente não há mais uma norma que liste cláusulas abusivas, como fazia o Ato Normativo no. 15. No entanto, deduz-se que existe um "entendimento do INPI”, que são regras não escritas e resultantes do pensamento dos examinadores sobre determinada matéria, baseadas principalmente nos Atos Normativos $15 / 75$ e 120/93, que, embora já revogados, continuam sendo a base para as decisões.

Conclui-se que, a despeito da previsão da LPI de que a função do registro e averbação do contrato no INPI é a oponibilidade a terceiros, o órgão faz uma análise substantiva do contrato e pode fazer exigências e indeferir a pretensão de registro ou averbação.

Mesmo assim, houve uma diminuição da intervenção e da esfera de atuação do INPI, o que pode causar um aumento da dependência tecnológica do Brasil. O crescimento do número de averbações de contratos de assistência técnica e do dinheiro remetido ao exterior é indicativo de que não está havendo assimilação de tecnologia pelas empresas nacionais, ou seja, efetiva transferência de tecnologia.

Conclui-se, por fim, que o estudo dos limites jurídicos impostos à autonomia das partes é relevante para que o contrato de transferência de tecnologia não seja nulo ou anulável. 


\section{REFERÊNCIAS}

ANTUNES, José Manuel Oliveira. Relações internacionais e transferência de tecnologia. Coimbra: Livraria Almedina, 1993.

ARAÚJO, Nádia de. Contratos internacionais: autonomia da vontade, Mercosul e convenções internacionais, 2 ed. Rio de Janeiro: Renovar, 2000.

BARBOSA, Denis Borges. Uma introdução à propriedade intelectual. 2. ed. Rio de Janeiro: Lumen Juris, 2003.

BETTI, Emílio. Teoria geral do negócio jurídico. Tradução de Ricardo Rodrigues Gama. Campinas: LZN Editora, 2003. Tomo 1.

BRASIL, Ato Normativo n.․․ 15 , do INPI. , Constituição Federal de 1988. Brasília,1988.

. Lei n.o 9279, de 14 de maio de 1996. Regula direitos e obrigações relativos à propriedade industrial. Brasília, 1996.

CORREAA, Daniel Rocha. Contratos de transferência de tecnologia: controle de práticas abusivas e cláusulas restritivas. Belo Horizonte: Movimento Editorial da Faculdade de Direito da UFMG, 2005.

DANNEMANN, Siemsen; BIGLER \& IPANEMA MOREIRA. Comentários à Lei de Propriedade Industrial e Correlatos. Rio de Janeiro: Renovar, 2001.

DINIZ, Maria Helena. Curso de Direito Civil Brasileiro. 23 ed. São Paulo: Saraiva, 2006. v. 3.

FLORES, César. Contratos de transferência de tecnologia: influência econômica. Rio de Janeiro: Lumen Juris, 2003.

FONTANA, Roseanne Lunardelli Salomon. Do Contrato de Transferência de Tecnologia. 2003. Dissertação de (Mestrado em Direito) - Pontifícia Universidade Católica do Paraná, Curitiba, 2003.

INPI. website (www.inpi.org.br). Acesso em: 3 maio 2006.

NUSDEO, Fábio. Curso de economia: introdução ao Direito Econômico. 3. ed. São Paulo: Editora Revista dos Tribunais, 2001.

PIMENTEL, Luiz Otávio. Direito Industrial: noções introdutórias. Chapecó: UNOESC, 1994.

. Normas jurídicas do comércio mundial: propriedade intelectual. 
Scientia Iuris, Londrina, v. 4, p. 223-257, 2000.

. Propriedade Industrial (Contratos de Transferência de Tecnologia).

Londrina, 2005. Aula da disciplina ministrada no Curso de Pós Graduação de Direito da Integração e Comércio Internacional, da Universidade Estadual de Londrina, 24 e 25 de junho de 2005.

. Contratos de Transferência de Tecnologia [palestra]. In: SEMINÁRIO A PROPRIEDADE INTELECTUAL COMO FATOR DE INTELIGÊNCIA COMPETITIVA, 3., 2005, Curitiba. [Anais...]. Curitiba: Tecpar, jun. 2005.

PRADO, Mauricio Curvelo de Almeida. Contrato internacional de transferência de tecnologia, patente e know-how. Porto Alegre: Livraria do Advogado, 1997.

SALOMÃO FILHO, Calixto. Regulação da atividade econômica (princípios e fundamentos jurídicos). São Paulo: Malheiros Editores, 2001.

Artigo recebido em 10/07/09 e aceito em 02/09/09 